Article

\title{
Novel AlN/Pt/ZnO Electrode for High Temperature SAW Sensors
}

\author{
Xingpeng Liu, Bin Peng *, Wanli Zhang, Jun Zhu, Xingzhao Liu and Meng Wei \\ State Key Laboratory of Electronic Thin Films and Integrated Devices, University of Electronic Science and \\ Technology of China, Chengdu 610054, China; tadyliu@outlook.com (X.L.); wlzhang@uestc.edu.cn (W.Z.); \\ junzhu@uestc.edu.cn (J.Z.); xzliu@uestc.edu.cn (X.L.); wm2lzx1314@hotmail.com (M.W.) \\ * Correspondence: bpeng@uestc.edu.cn; Tel.: +86-28-8320-1475
}

Academic Editor: Federico Bella

Received: 7 November 2016; Accepted: 9 January 2017; Published: 16 January 2017

\begin{abstract}
In order to develop a film electrode for the surface acoustic wave (SAW) devices working in high temperature, harsh environments, novel $\mathrm{AlN} / \mathrm{Pt} / \mathrm{ZnO}$ multilayers were prepared using pulsed laser deposition (PLD) systems on langasite (LGS) substrates. The AlN film was used as a protective layer and the $\mathrm{ZnO}$ buffer layer was introduced to improve the crystal quality of $\mathrm{Pt}$ films. The results show that the resistances of $\mathrm{Pt}$ and AlN/Pt film electrodes violently increase above $600{ }^{\circ} \mathrm{C}$ and $800^{\circ} \mathrm{C}$, respectively, while the resistances of $\mathrm{AlN} / \mathrm{Pt} / \mathrm{ZnO}$ electrodes have more stable electrical resistance from room temperature to $1000{ }^{\circ} \mathrm{C}$. The $\mathrm{AlN} / \mathrm{Pt} / \mathrm{ZnO}$ electrode, where the $\mathrm{ZnO}$ film was deposited at $600{ }^{\circ} \mathrm{C}$, has the best temperature stability and can steadily work for $4 \mathrm{~h}$ at $1000^{\circ} \mathrm{C}$. The mechanism underlying the stable resistance of the $\mathrm{AlN} / \mathrm{Pt} / \mathrm{ZnO}$ electrode at a high temperature was investigated by analyzing the microstructure of the prepared samples. The proposed $\mathrm{AlN} / \mathrm{Pt} / \mathrm{ZnO}$ film electrode has great potential for applications in high temperature SAW sensors.
\end{abstract}

Keywords: high temperature electrode; SAW sensor; electrical resistance; langasite

\section{Introduction}

Many efforts in recent years have been focused on surface acoustic wave (SAW) sensors [1,2], mainly due to their excellent wireless, passive, small, multifunctional quality, and their ability to be widely applied to systems sensing temperature [3], pressure [4], and strain [5] et al. With the progress of science and technology, these SAW sensors, which work in high temperature, harsh environments, are in high demand [6]. The major challenge of SAW sensors operating at high temperatures is to prepare stable high temperature film electrodes, since film electrodes such as $\mathrm{Pt}$ [7], Pt-Rh [8], Ir-Rh [9], Ru-Al [10], W/Mo [11], W [12], or Pt-Ni/Pt-Zr [13] film electrodes, always undergo rapid agglomeration and recrystallization above $700{ }^{\circ} \mathrm{C}$, resulting in the discontinuity of film electrodes, an increase in resistance, and a failure of the SAW sensor. Until now, many researchers have made much effort to solve this problem. Moulzolf $[8,14]$ co-deposited $\mathrm{Pt} / \mathrm{Rh}(10 \%)$ as a film electrode and used $\mathrm{HfO}_{2}$ as a passivation coating to hinder agglomeration and recrystallization. Taguetta [9] used Ir-Rh alloy electrodes with different compositions and found that the Ir-Rh film electrodes with optimum composition ratio can tolerate temperatures as high as $800{ }^{\circ} \mathrm{C}$. Rane [12] used tungsten film electrodes to prevent the diffusion of $\mathrm{Ga}$ and $\mathrm{O}$ atoms from the substrate, into the tungsten film, and obtained stable electrodes up to $800{ }^{\circ} \mathrm{C}$. Seifert [15] prepared $\mathrm{RuAl}$ film electrodes with a $\mathrm{SiO}_{2}$ barrier, which was able to work stably at $800{ }^{\circ} \mathrm{C}$ for $10 \mathrm{~h}$. However, the SAW electrode was unable to steadily work above $1000{ }^{\circ} \mathrm{C}$ because the recrystallization phenomenon of the electrode film was difficult to prevent.

From the previous reports, it can be seen that the agglomeration and recrystallization of metal electrodes always occur at a high temperature. We think that one of the reasons underlying this is that 
the as-deposited metal film electrode is not crystallized fully, or that the crystal quality of the metal film electrode is poor. Because of this, the metal film electrode recrystallizes at a high temperature and its resistance increases dramatically. Therefore, we would predict that the stability of a film electrode at a high temperature can be improved if the as-deposited film electrode is already well-grown, with a good crystal quality. In this work, we deposited Pt film electrodes on Langasite (LGS) piezoelectric substrate, because LGS substrate can work at high temperatures [16]. The LGS substrates which we used are inclined and cut with an irregular orientation, so the Pt film electrode deposited directly on them doesn't have a good crystal structure. To solve this problem, we chose $\mathrm{ZnO}$ as a buffer layer because the use of a $\mathrm{ZnO}$ film is a very easy way of forming an orientation texture $[17,18]$. Besides, $\mathrm{ZnO}$ film was introduced as a buffer layer for Pt film electrodes because the lattice mismatch between $\mathrm{Pt}$ and $\mathrm{ZnO}$ is small, and the $\mathrm{ZnO}$ buffer layer is then able to prompt the crystallization and preferential (111) orientation growth of the Pt film [19]. Finally, an AlN capping layer was deposited on the Pt film and acted as a passive coating. The characteristics of the proposed AlN/Pt/ZnO film electrodes, from room temperature to $1000^{\circ} \mathrm{C}$, have been explored.

\section{Results and Discussion}

Figure 1 shows the real-time, relative resistance change $\left(\Delta R / R_{r t}\right)$ as a function of temperature for Pt/LGS, AlN/Pt/LGS, AlN/Pt/ZnO(RT)/LGS, AlN/Pt/ZnO(600 $\left.{ }^{\circ} \mathrm{C}\right) / \mathrm{LGS}$ samples, where $\mathrm{R}_{\mathrm{rt}}$ is the resistance of the sample at room temperature and $\Delta \mathrm{R}$ is the difference between the resistances at high temperature and room temperature. It can be seen that the resistance of the $\mathrm{Pt} / \mathrm{LGS}$ sample sharply increases above $600{ }^{\circ} \mathrm{C}$, and increases by 22 times when it is heated to $800{ }^{\circ} \mathrm{C}$, from room temperature. The resistance of the AlN/Pt/LGS sample increases slowly below $800^{\circ} \mathrm{C}$ and increases by eight times when it is heated to $1000{ }^{\circ} \mathrm{C}$, from room temperature. It can be seen that the resistance of the AlN/Pt/LGS electrode continues to increase at a remarkable rate, though the AlN capping layer can improve the stability of the $\mathrm{Pt}$ film electrode to some extent, by comparing the resistance of $\mathrm{Pt} / \mathrm{LGS}$ and of AlN/Pt/LGS samples. It is interesting to note that the resistance of the AlN/Pt/ZnO(RT)/LGS sample changes very slowly between room temperature and $1000{ }^{\circ} \mathrm{C}$. The relative resistance change of the $\mathrm{AlN} / \mathrm{Pt} / \mathrm{ZnO}(\mathrm{RT}) / \mathrm{LGS}$ sample is about $82 \%$ at $1000{ }^{\circ} \mathrm{C}$, which indicates that the $\mathrm{ZnO}$ buffer layer plays a prominent role in hindering the degradation of $\mathrm{Pt}$ film electrodes. Furthermore, it can be observed that the resistance of the $\mathrm{AlN} / \mathrm{Pt} / \mathrm{ZnO}\left(600^{\circ} \mathrm{C}\right) / \mathrm{LGS}$ sample is more stable than that of the $\mathrm{AlN} / \mathrm{Pt} / \mathrm{ZnO}(\mathrm{RT}) / \mathrm{LGS}$ sample. The relative resistance change of the $\mathrm{AlN} / \mathrm{Pt} / \mathrm{ZnO}\left(600{ }^{\circ} \mathrm{C}\right) / \mathrm{LGS}$ sample is only about $17 \%$ at $1000^{\circ} \mathrm{C}$, which means that this $\mathrm{AlN} / \mathrm{Pt} / \mathrm{ZnO}\left(600{ }^{\circ} \mathrm{C}\right) / \mathrm{LGS}$ electrode is stable enough to work at room temperature and $1000{ }^{\circ} \mathrm{C}$.

When studying Figure 1, it is clear to view that the resistance changes of these four samples vary. The resistance change of the metal film electrode is dependent on its microstructure. In order to investigate the changes in these samples, before and after being exposed to a high temperature, microstructural analyses were performed by using SEM and XRD. Figure 2 shows the surface topography of $\mathrm{Pt} / \mathrm{LGS}$ and AlN/Pt/LGS samples before and after high temperature resistance measurements have been recorded. When looking at Figure 2a, it can be observed that the surface topography of the $\mathrm{Pt} / \mathrm{LGS}$ sample before measurement is smooth, showcasing no big grains. However, after the $800{ }^{\circ} \mathrm{C}$ and $1000{ }^{\circ} \mathrm{C}$ resistance measurement, completely isolated grains appear at the surface of the Pt/LGS sample, as shown in Figure 2b,c, indicating that the Pt film experiences agglomeration and recrystallization above $800^{\circ} \mathrm{C}$. As can be seen in Figure $2 \mathrm{c}$, the grain size is about $1 \mu \mathrm{m}$. As a result of this, the Pt film becomes discontinuous and loses its electrical conductivity at high temperatures. Similarly, we can view that the AlN/Pt/LGS sample also exhibits a smooth surface without obvious big grains before measurements are taken, as shown in Figure $2 \mathrm{~d}$. After the $800{ }^{\circ} \mathrm{C}$ resistance measurement, some discontinuities appear on the surface of the AlN/Pt/LGS sample, as shown in Figure 2e, indicating that the agglomeration and recrystallization is partly prevented. This result demonstrates the increasingly stable electrical conductivity of the AlN/Pt/LGS sample than the $\mathrm{Pt} / \mathrm{LGS}$ sample above $800{ }^{\circ} \mathrm{C}$, as shown in Figure 1. Additionally, the surface topography of the 
AlN/Pt/LGS sample after the $1000{ }^{\circ} \mathrm{C}$ resistance measurement is shown in Figure $2 \mathrm{f}$ which reveals completely isolated grains with a smaller size $(500 \mathrm{~nm})$, leading to a sharp decrease in electrical conductivity above $800{ }^{\circ} \mathrm{C}$. The insets in Figure $2 \mathrm{~d}$,f show the surface topography of the AlN/LGS sample before and after the $1000{ }^{\circ} \mathrm{C}$ resistance measurement, respectively. No obvious grains are observed after this measurement, which indicates that the appearance of big grains in the AlN/Pt/LGS samples derive from the Pt film rather than the AlN film.

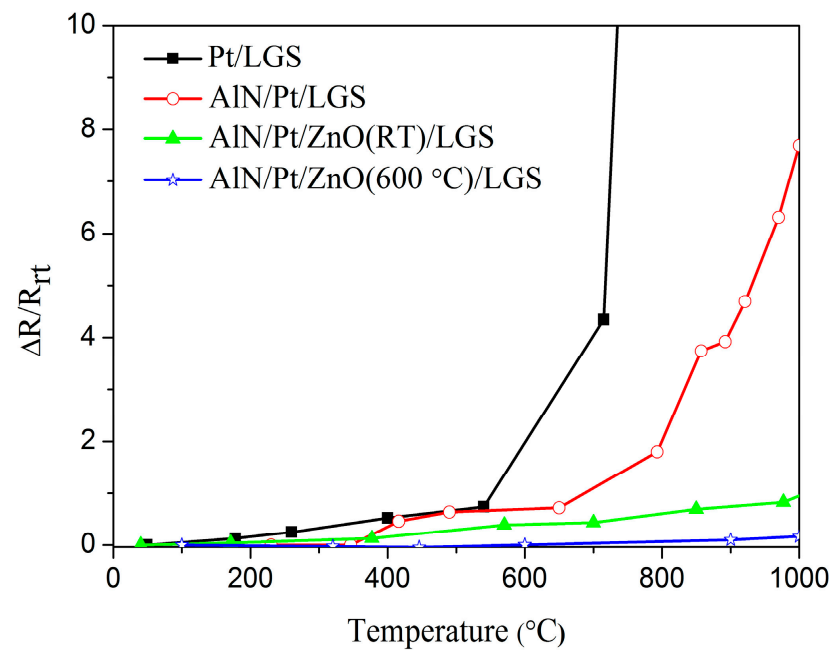

Figure 1. Relative resistance change for different samples as a function of temperature. The AlN $/ \mathrm{Pt} / \mathrm{ZnO}(\mathrm{RT}) / \mathrm{LGS}$ and $\mathrm{AlN} / \mathrm{Pt} / \mathrm{ZnO}\left(600{ }^{\circ} \mathrm{C}\right) / \mathrm{LGS}$ samples correspond to the $\mathrm{AlN} / \mathrm{Pt} / \mathrm{ZnO} / \mathrm{LGS}$ samples where the $\mathrm{ZnO}$ film was deposited at room temperature and $600{ }^{\circ} \mathrm{C}$, respectively.
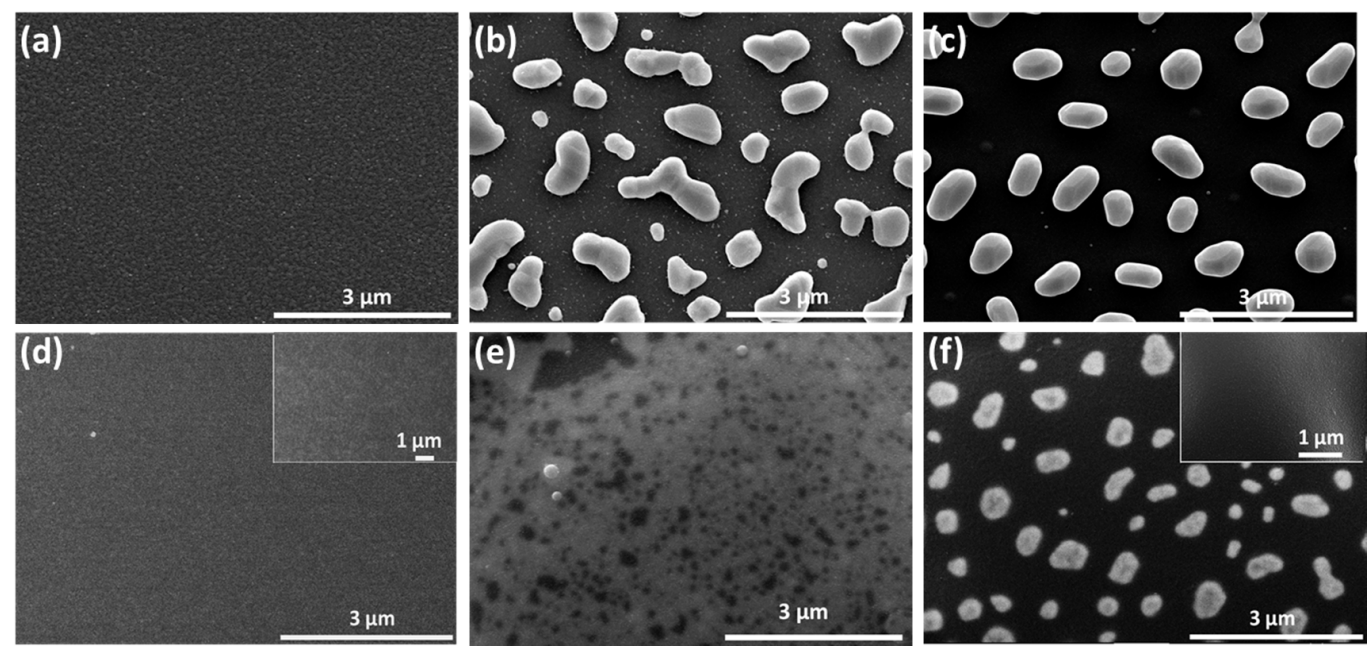

Figure 2. Surface topography of Pt/LGS samples (a) before high temperature measurement; and (b) after $800{ }^{\circ} \mathrm{C}$ resistance measurement; and (c) after $1000{ }^{\circ} \mathrm{C}$ resistance measurement; Surface topography of AlN/Pt/LGS samples (d) before high temperature measurement; and (e) after 800 ${ }^{\circ} \mathrm{C}$ resistance measurement; and (f) after $1000{ }^{\circ} \mathrm{C}$ resistance measurement. Insets shown in (d); and (f) present the surface topography of AIN/LGS samples before and after $1000{ }^{\circ} \mathrm{C}$ resistance measurement, respectively.

Figure 3 shows the $\theta-2 \theta$ XRD scan and omega scan of the AlN/Pt/LGS sample, both before and after the $1000{ }^{\circ} \mathrm{C}$ resistance measurement. No obvious peak can be identified from the XRD curve before measurement. However, a clear $\mathrm{Pt}$ (111) peak appears after the $1000{ }^{\circ} \mathrm{C}$ resistance 
measurement. These results suggest that either the Pt film is not crystalized, or that the crystalline quality is poor before measurement, and that the Pt film only crystallized after the high temperature measurement. It can thus be concluded that the Pt phase witnessed great recrystallization and formed completely isolated grains, leading to the remarkable increase in resistance. The FWHM of the Pt (111), characterized by the $\omega$ scan as shown in Figure $3 b$, was as large as $22^{\circ}$, indicating that the crystal quality isn't good enough. At the same time, no AlN peaks were identified in Figure 3a. We think that this may be due to the low precision of our X-ray diffraction and the low thickness of our AlN top layer. In general, only the AlN films with a thickness of a several hundred nanometers can show obvious AlN peaks [20-22]. However, the thickness of the AlN film in our work is only about $30 \mathrm{~nm}$.
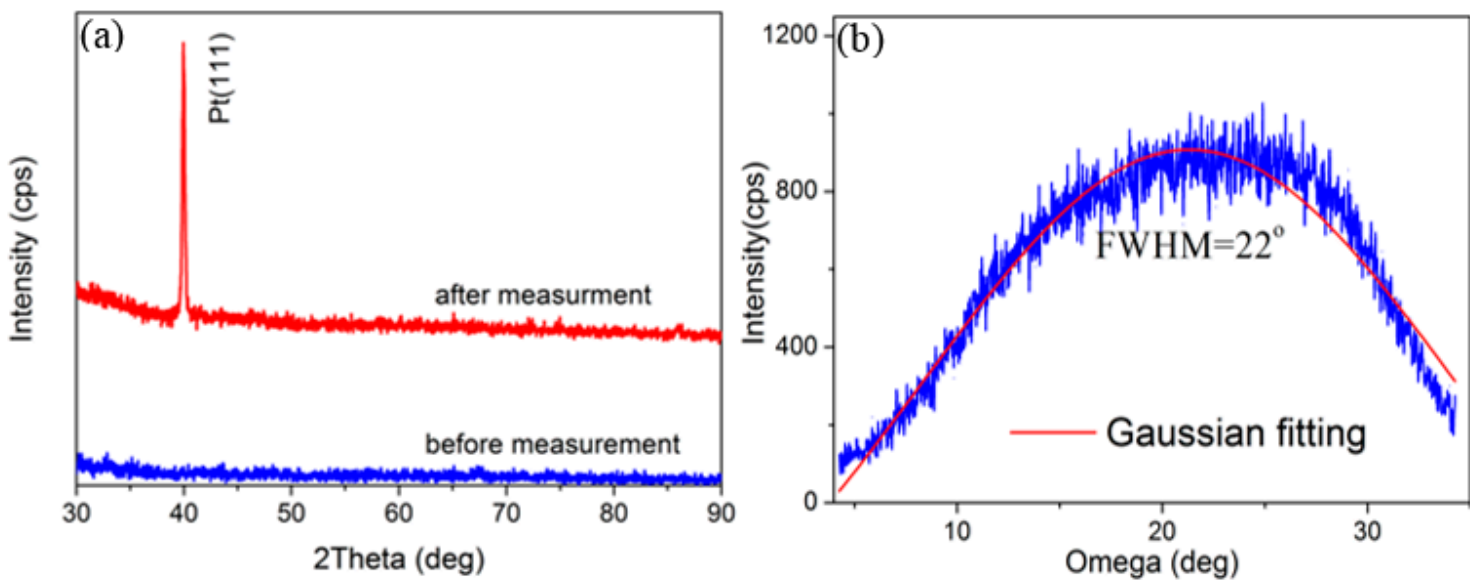

Figure 3. (a) $\theta-2 \theta$ scans of AlN/Pt/LGS samples before and after high temperature measurement; (b) Rocking curve of $\mathrm{Pt}$ (111) of AlN/Pt/LGS samples after high temperature measurement.

From the microstructure evolution of the AlN/Pt/LGS sample before and after high temperature, we expect that the stability of the Pt film at high temperature can be improved, if we can deposit a Pt film with good crystalline quality. Next, we discuss the effects of the $\mathrm{ZnO}$ buffer layer on the microstructure of the $\mathrm{Pt}$ film at high temperature. The cross-sectional SEM image of AlN/Pt/ZnO(RT)/LGS is shown in Figure 4. From this SEM result, we can clearly observe that there are three film layers, representing $\mathrm{ZnO}, \mathrm{Pt}$, and AlN films, respectively. The surface topography of the AlN/Pt/ZnO(RT)/LGS sample and the $\mathrm{AlN} / \mathrm{Pt} / \mathrm{ZnO}\left(600{ }^{\circ} \mathrm{C}\right) / \mathrm{LGS}$ sample, before and after the $1000{ }^{\circ} \mathrm{C}$ measurement, are shown in Figure 5.

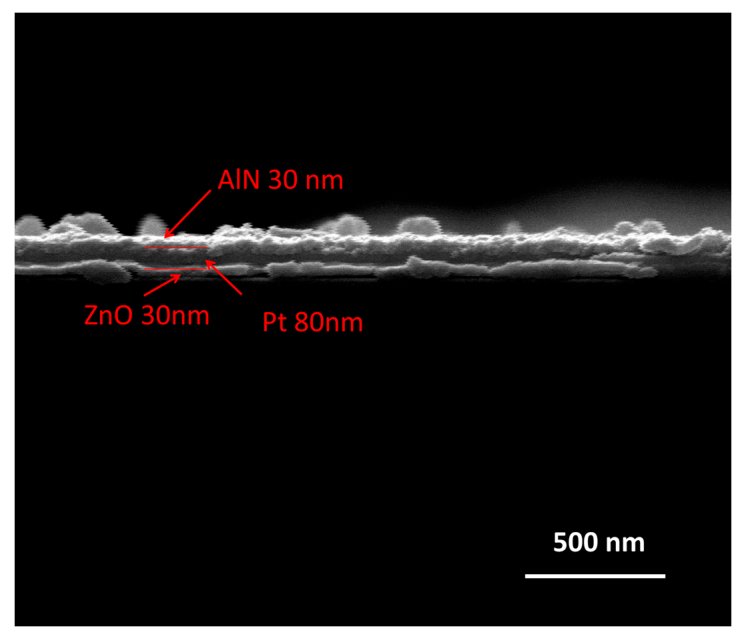

Figure 4. SEM image of the cross-section of the AlN/Pt/ZnO(RT)/LGS sample. 

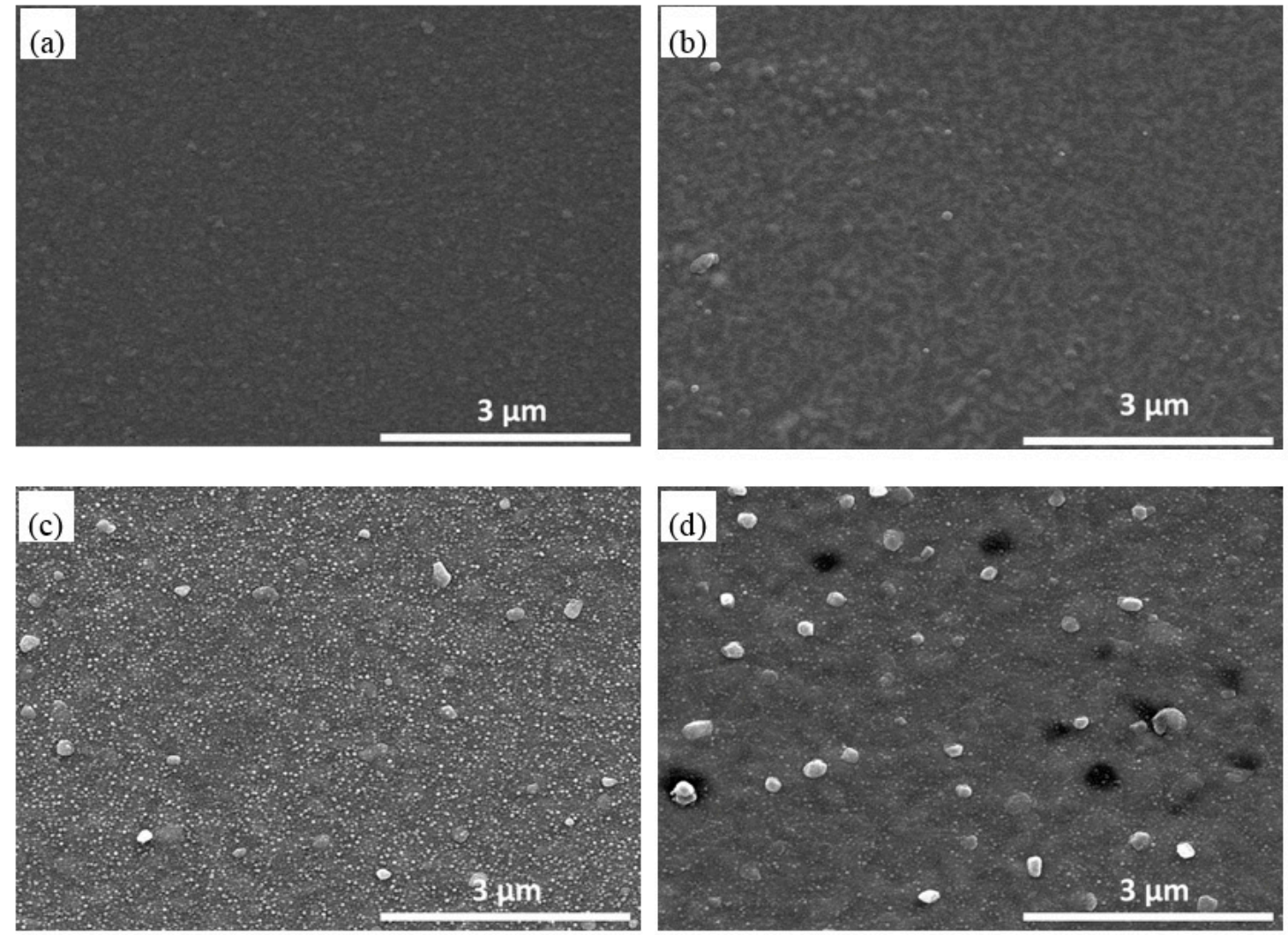

Figure 5. Surface topography of $\mathrm{AlN} / \mathrm{Pt} / \mathrm{ZnO}(\mathrm{RT}) / \mathrm{LGS}$ samples (a) before; and (b) after $1000{ }^{\circ} \mathrm{C}$ resistance measurement. Surface topography of $\mathrm{AlN} / \mathrm{Pt} / \mathrm{ZnO}\left(600{ }^{\circ} \mathrm{C}\right) / \mathrm{LGS}$ samples; (c) before; and (d) after $1000{ }^{\circ} \mathrm{C}$ resistance measurement.

For $\mathrm{AlN} / \mathrm{Pt} / \mathrm{ZnO}(\mathrm{RT}) / \mathrm{LGS}$ samples, the surface topography before the $1000{ }^{\circ} \mathrm{C}$ measurement is shown in Figure 5a. The surface is smooth and there are no obvious grains. However, after the high temperature measurement, we can observe many discontinuities and small grains in Figure $5 \mathrm{~b}$. These are different to the completely isolated Pt grains in Figure 2c, and are small, without being completely isolated. Because of this, the resistance of the AlN/Pt/ZnO(RT)/LGS sample after the high temperature measurement only increased slightly. A comparison of the surface topography of $\mathrm{AlN} / \mathrm{Pt} / \mathrm{ZnO}\left(600^{\circ} \mathrm{C}\right)$ samples before and after the high temperature measurement are shown in Figure $5 c$,d. Figure $5 c$ presents many extreme small grains and few big grains. These small grains are considered to be AlN particles. Following the high temperature measurement, no obvious isolated grains appeared, thus leading to a stable electrical conductivity, partly explaining the horizontal straight curve of $\mathrm{AlN} / \mathrm{Pt} / \mathrm{ZnO}\left(600{ }^{\circ} \mathrm{C}\right) / \mathrm{LGS}$ shown in Figure 1. Furthermore, a high number of small grains disappeared after the high temperature measurement, indicating that the AlN phase recrystallized during the high temperature measurement and formed a big crystal.

Figure 6 shows the $\theta-2 \theta$ scan and omega scan of the AlN/Pt/ZnO(RT)/LGS samples and the $\mathrm{AlN} / \mathrm{Pt} / \mathrm{ZnO}\left(600{ }^{\circ} \mathrm{C}\right) / \mathrm{LGS}$ samples before and after the high temperature measurement. When studying Figure 6a, we can see that the $\mathrm{Pt}$ (111) peak with low intensity appears before the measurement has been taken. The low intensity, and the large FWHM shown in Figure 6b, indicate that the Pt phase formed a preferential (111) orientation with poor crystal quality when it was deposited at room temperature. After the $1000{ }^{\circ} \mathrm{C}$ resistance measurement, the intensity of the $\mathrm{Pt}$ (111) peak violently increased, and the FWHM decreased from $20^{\circ}$ to $6.5^{\circ}$, indicating that the Pt phase was still recrystallized at high temperature. The pre-existing preferential $\mathrm{Pt}$ (111) orientation is considered to play an important role in partly weakening the recrystallization at high temperature, and thus the $\mathrm{AlN} / \mathrm{Pt} / \mathrm{ZnO}$ (RT) electrode films obtained more stable electrical conductivity at a high temperature 
than the AlN/Pt electrode. As a comparison, the sample deposited at $600{ }^{\circ} \mathrm{C}$ presents a $\mathrm{Pt}(111)$ peak with high intensity and small FWHM before the $1000{ }^{\circ} \mathrm{C}$ resistance measurement, as shown in Figure $6 c$, indicating that the Pt film has good crystal quality before the high temperature measurement. After this measurement, both the intensity of the Pt (111) peak and the FWHM almost remained the same, and it shows that the recrystallization was almost totally prevented due to the pre-existing good crystal quality.
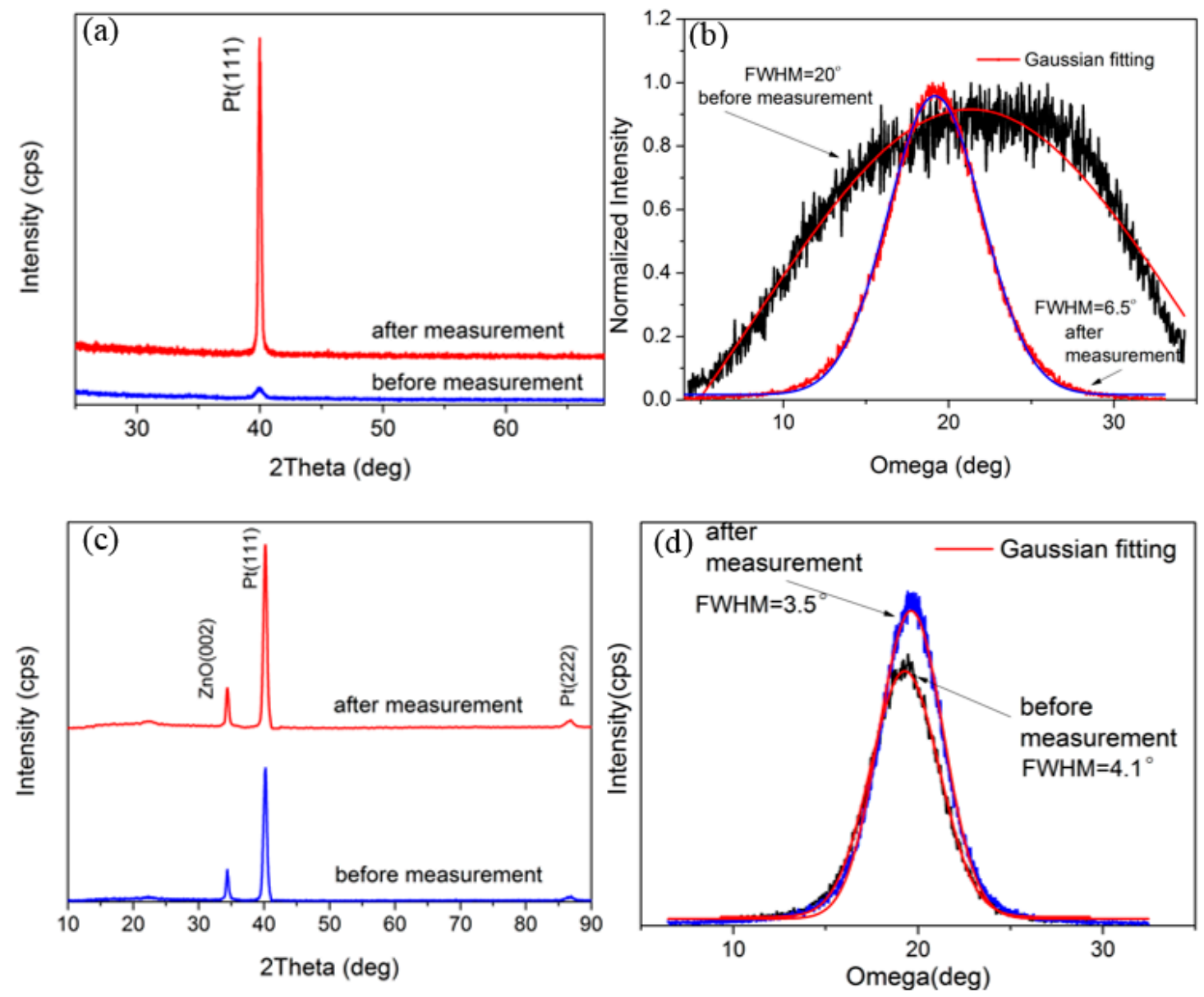

Figure 6. (a) $\theta-2 \theta$ scan; and (b) rocking curves of the AlN/Pt/ZnO(RT)/LGS samples before and after $1000^{\circ} \mathrm{C}$ resistance measurement; (c) $\theta-2 \theta$ scan; and (d) rocking curves of the $\mathrm{AlN} / \mathrm{Pt} / \mathrm{ZnO}\left(600^{\circ} \mathrm{C}\right) / \mathrm{LGS}$ samples before and after $1000{ }^{\circ} \mathrm{C}$ resistance measurement.

Figure 7 shows the real-time relative resistance measurement of $\mathrm{AlN} / \mathrm{Pt} / \mathrm{ZnO}(\mathrm{RT}) / \mathrm{LGS}$ and $\mathrm{AlN} / \mathrm{Pt} / \mathrm{ZnO}\left(600{ }^{\circ} \mathrm{C}\right) / \mathrm{LGS}$ samples at $1000{ }^{\circ} \mathrm{C}$ for $4 \mathrm{~h}$, where $\mathrm{R}_{1000, t=0}$ represents the value of resistance at the beginning of the measurement at $1000{ }^{\circ} \mathrm{C}$. During the $4 \mathrm{~h}$ heat preservation process, the resistance of the $\mathrm{AlN} / \mathrm{Pt} / \mathrm{ZnO}(\mathrm{RT}) / \mathrm{LGS}$ sample slowly increased by 1.6 times and the resistance of the $\mathrm{AlN} / \mathrm{Pt} / \mathrm{ZnO}\left(600{ }^{\circ} \mathrm{C}\right) / \mathrm{LGS}$ sample remained the same. Because the Pt film became more isolated, as shown in Figure $5 b$, the electronic transmission paths of the AlN/Pt/ZnO(RT) electrode became fewer and more crowded, resulting in a loss in conductivity. As a comparison, the resistance of the $\mathrm{AlN} / \mathrm{Pt} / \mathrm{ZnO}\left(600^{\circ} \mathrm{C}\right) / \mathrm{LGS}$ sample didn't increase during the preservation process at $1000{ }^{\circ} \mathrm{C}$, due to the more stable structrue of the Pt phase at $1000{ }^{\circ} \mathrm{C}$, which derived from better crystal quality. In this case, the Pt film has better continuity, resulting in a better stability of the electric conductivity at a high temperature. Compared to other multi-layer-films losing part of their electrical conductivity after annealing at $1000{ }^{\circ} \mathrm{C}$ for $4 \mathrm{~h}$, like Pt-Ni multilayer films [13], these $\mathrm{AlN} / \mathrm{Pt} / \mathrm{ZnO}\left(600{ }^{\circ} \mathrm{C}\right)$ electrode 
films present more stability in their electrical conductivity after the $1000^{\circ} \mathrm{C}$ resistance measurement for $4 \mathrm{~h}$, because of the pre-existing good crystal quality of the $\mathrm{Pt}(111)$ phase.

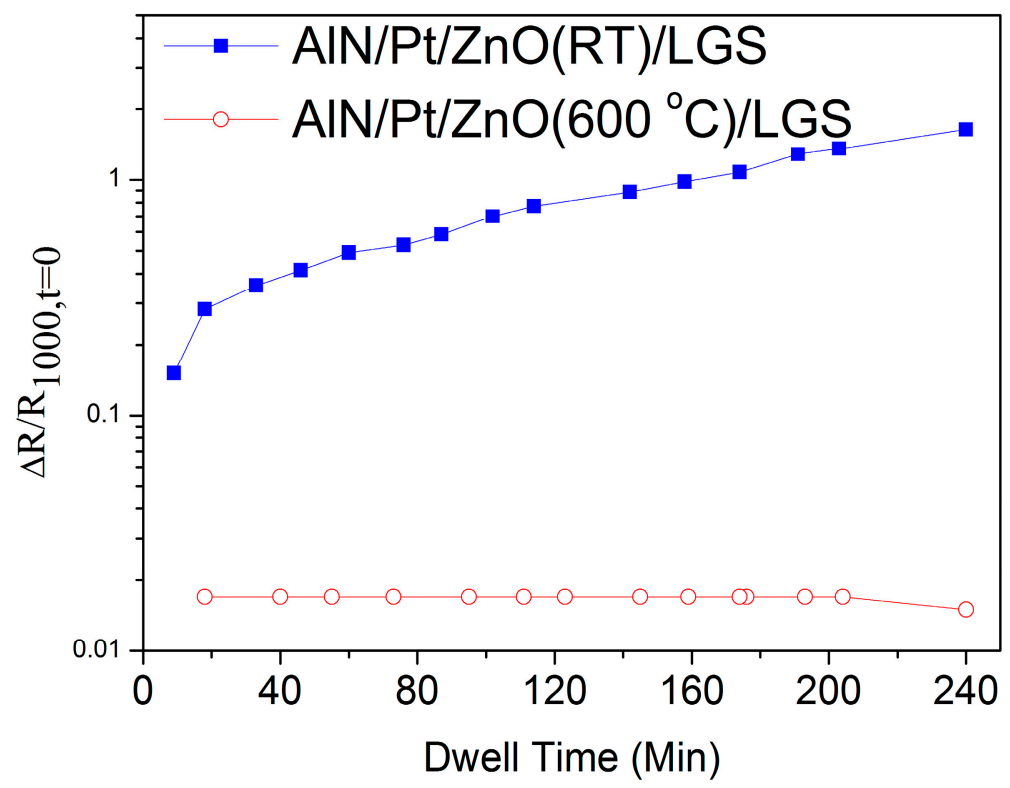

Figure 7. Relative resistance change of $\mathrm{AlN} / \mathrm{Pt} / \mathrm{ZnO}(\mathrm{RT}) / \mathrm{LGS}$ and $\mathrm{AlN} / \mathrm{Pt} / \mathrm{ZnO}\left(600{ }^{\circ} \mathrm{C}\right) / \mathrm{LGS}$ samples as a function of time at $1000^{\circ} \mathrm{C}$ for $4 \mathrm{~h}$.

\section{Materials and Methods}

All films were prepared in a pulsed laser MBE system, using a $\operatorname{KrF}(\lambda=248 \mathrm{~nm})$ excimer laser (lambda physic, Goettingen, Germany). Highly purified AlN, Pt, and ZnO targets were used in this work and the distance from the target to the substrate was $5 \mathrm{~cm}$. The $\mathrm{AlN} / \mathrm{Pt} / \mathrm{ZnO}$ electrodes were deposited on LGS piezoelectric substrate, cut with Euler angle of $\left(0^{\circ}, 138.5^{\circ}\right.$ and $\left.116.6^{\circ}\right)$. The thickness of AlN, Pt, and ZnO layers were 30, 80, and $30 \mathrm{~nm}$, respectively. Before being deposited, the LGS substrates were ultrasonically cleaned in anhydrous alcohol for $6 \mathrm{~min}$, followed by a $\mathrm{N}_{2}$ drying process. Then, the substrates were put into the deposition chamber. During the entire depositing process of $\mathrm{AlN} / \mathrm{Pt} / \mathrm{ZnO}$ samples, the base pressure was set at $5 \times 10^{-5} \mathrm{~Pa}$. $\mathrm{ZnO}$ was directly deposited on the LGS substrate as a buffer layer for $30 \mathrm{~min}$. The substrate temperature was kept at room temperature or $600{ }^{\circ} \mathrm{C}$ during depositing $\mathrm{ZnO}$ films. The samples were named as AlN/Pt/ZnO (RT) and $\mathrm{AlN} / \mathrm{Pt} / \mathrm{ZnO}\left(600^{\circ} \mathrm{C}\right)$, respectively. The laser energy density was about $4 \mathrm{~J} \cdot \mathrm{cm}^{-2}$ at a frequency of $2 \mathrm{~Hz}(30 \mathrm{~nm})$. Next, the Pt film was deposited on the $\mathrm{ZnO}$ buffer layer, with a laser energy of $6 \mathrm{~J} \cdot \mathrm{cm}^{-2}$ at a frequency of $1 \mathrm{~Hz}$ for $1 \mathrm{~h}(80 \mathrm{~nm})$. Finally, the AlN capping layer was deposited on the Pt films for $20 \mathrm{~min}$, with a laser energy of $4 \mathrm{~J} \cdot \mathrm{cm}^{-2}$ at a frequency of $2 \mathrm{~Hz}(30 \mathrm{~nm})$. In order to better understand the role of the $\mathrm{ZnO}$ buffer layer, $\mathrm{Pt}$ and $\mathrm{AlN} / \mathrm{Pt}$ electrodes without $\mathrm{ZnO}$ buffer layer were also deposited on LGS substrates at room temperature, with the same thickness and the same depositing conditions.

The resistances of the samples were measured from room temperature to $1000{ }^{\circ} \mathrm{C}$ in air, within a tube furnace with a resistance meter (Keithley 2400, Microlease, Cary, NC, USA). The heating rate was $4{ }^{\circ} \mathrm{C}$ per minute. After the high temperature resistance measurement had been taken, the samples were cooled down to room temperature in a natural cooling condition. Film crystalline structure and texture were measured by X-ray diffraction (D1, Bede X-ray Metrology, Durham, UK), both before and after the high temperature resistance measurement. An omega scan and $\theta-2 \theta$ scan were both performed in order to precisely characterize the orientation of the metal film electrodes. A scanning electron microscope (JSM-7500F, JEOL, Peabody, MA, USA) was used to characterize the surface topography of the samples, both before and after the high temperature resistance measurement. 


\section{Conclusions}

In this work, $\mathrm{ZnO}$ film is introduced as a buffer layer in order to improve the crystal quality of the $\mathrm{Pt}$ film, so that the recrystallization of the Pt phase is hindered at a high temperature. In this way, the stability of the electrical resistance of the novel $\mathrm{AlN} / \mathrm{Pt} / \mathrm{ZnO}$ multilayer films electrode, at is greatly improved when at $1000{ }^{\circ} \mathrm{C}$. It is found that the AlN capping layer can improve the stability of the Pt film electrode, to some extent. The $\mathrm{ZnO}$ buffer layer can prompt the preferential (111) orientation growth of Pt films, thereby hindering the recrystallization in Pt films with great (111) preferred orientation. This is especially the case for the $\mathrm{AlN} / \mathrm{Pt} / \mathrm{ZnO}\left(600{ }^{\circ} \mathrm{C}\right)$ electrode, which can steadily work at $1000{ }^{\circ} \mathrm{C}$ for at least $4 \mathrm{~h}$. It suggests that the recrystallization of $\mathrm{Pt}$ films is dependent on their crystal quality. The proposed $\mathrm{AlN} / \mathrm{Pt} / \mathrm{ZnO}$ electrode structure has great potential for applications not only in SAW sensors, but also in other sensors which work in high temperature, harsh environments.

Acknowledgments: This work is financially supported by NSFC (No. 61223002).

Author Contributions: Xingpeng Liu and Bin Peng designed the experiments; Xingpeng Liu performed the experiments; Wanli Zhang and Jun Zhu analyzed the data; Xingzhao Liu and Meng Wei contributed the materials; Bin Peng and Xingpeng Liu wrote the paper.

Conflicts of Interest: The authors declare no conflict of interest.

\section{References}

1. Jang, Y.; Tan, C.Y. SAW sensor for Influenza A virus detection enabled with efficient surface functionalization. Sens. Actuators B Chem. 2015, 209, 78-84. [CrossRef]

2. Dixon, B.; Kalinin, V.; Beckley, J.; Lohr, R. A second generation in-car tire pressure monitoring system based on wireless passive SAW sensors. In Proceedings of the 2006 IEEE International Frequency Control Symposium and Exposition, Miami, FL, USA, 4-7 June 2006; pp. 374-380.

3. Kang, A.; Zhang, C.R. SAW-RFID enabled temperature sensor. Sens. Actuators A Phys. 2013, 201, $105-113$. [CrossRef]

4. Rodriguez-Madrid, J.G.; Iriarte, G.F. High precision pressure sensors based on SAW devices in the GHz range. Sens. Actuators A Phys. 2013, 189, 364-369. [CrossRef]

5. Shu, L.; Peng, B.; Yang, Z.B. High-temperature SAW wireless strain sensor with langasite. Sensors 2015, 15, 28531-28542. [CrossRef] [PubMed]

6. Mrosk, J.W.; Berger, L.; Ettl, C. Materials issues of SAW sensors for high-temperature applications. IEEE Trans. Ind. Electron. 2001, 48, 258-264. [CrossRef]

7. Meulendyk, B.J.; da Cunha, M.P. Transverse waveguide mode suppression for Pt-electrode SAW resonators on quartz and LGS. IEEE Trans. Ultrason. Ferroelectr. Freq. Control 2011, 58, 2727-2736. [CrossRef] [PubMed]

8. Moulzolf, S.C.; Frankel, D.J.; da Cunha, M.P. Electrically conductive Pt-Rh/ $\mathrm{ZrO}_{2}$ and $\mathrm{Pt}-\mathrm{Rh} / \mathrm{HfO} 2$ nanocomposite electrodes for high temperature harsh environment sensors. In Proceedings of the Conference on Smart Sensors, Actuators, and MEMS VI, Grenoble, France, 24-26 April 2013.

9. Taguetta, A.; Auberta, T.; Lomello, O. Ir-Rh thin films as high-temperature electrodes for surface acoustic wave sensor applications. Sens. Actuators A Phys. 2016, 243, 35-42. [CrossRef]

10. Seifert, M.; Menzel, S.B.; Rane, G.K. RuAl thin films on high-temperature piezoelectric substrates. Mater. Res. Express 2015, 2, 085001. [CrossRef]

11. Rane, G.K.; Menzel, S.; Seifert, M. Tungsten/molybdenum thin films for application as interdigital transducers on high temperature stable piezoelectric substrates $\mathrm{La}_{3} \mathrm{Ga}_{5} \mathrm{SiO}_{14}$ and $\mathrm{Ca}_{3} \mathrm{TaGa}_{3} \mathrm{Si}_{2} \mathrm{O}_{14}$. Mater. Sci. Eng. B Adv. Funct. Solid State Mater. 2015, 202, 31-38. [CrossRef]

12. Rane, G.K.; Seifert, M.; Menzel, S. Tungsten as a chemically-stable electrode material on Ga-containing piezoelectric substrates langasite and catangasite for high-temperature SAW devices. Materials 2016, 9, 101. [CrossRef]

13. Da Cunha, M.P.; Maskay, A.; Lad, R.J. Pt-Ni/Pt-Zr electrodes for stable SAW resonator operation during repeated temperature cycling up to $1000^{\circ} \mathrm{C}$. In Proceedings of the IEEE International Ultrasonics Symposium, Taipei, Taiwan, 21-24 October 2015. 
14. Moulzolf, S.C.; Frankel, D.J.; Bernhardt, G.P. Thin film electrodes and passivation coatings for harsh environment microwave acoustic sensors. In Proceedings of the Conference on Smart Sensors, Actuators, and MEMS V, Prague, Czech Republic, 18-20 April 2011.

15. Seifert, M.; Rane, G.K.; Menzel, S.B. The influence of barrier layers $\left(\mathrm{SiO}_{2}, \mathrm{Al}_{2} \mathrm{O}_{3}, \mathrm{~W}\right)$ on the phase formation and stability of RuAl thin films on LGS and CTGS substrates for surface acoustic wave technology. J. Alloys Compd. 2016, 688, 228-240. [CrossRef]

16. Bao, S.M.; Ke, Y.B.; Zheng, Y.Q. A method for achieving monotonic frequency-temperature response for langasite surface-acoustic-wave high-temperature sensor. Jpn. J. Appl. Phys. 2016, 55, 027301.

17. Bortoleto, J.R.R.; Chaves, M.; Rosa, A.M.; da Silva, E.P.; Durrant, S.F.; Trino, L.D.; Lisboa-Filho, P.N. Growth evolution of self-textured $\mathrm{ZnO}$ films deposited by magnetron sputtering at low temperatures. Appl. Surf. Sci. 2015, 334, 210-215. [CrossRef]

18. Wang, M.S.; Kim, E.J.; Shin, E.W.; Chung, J.S.; Hahn, S.H.; Park, C. Low-temperature solution growth of high-quality $\mathrm{ZnO}$ thin films and solvent-dependent film texture. J. Phys. Chem. C 2008, 112, 1920-1924. [CrossRef]

19. Ramachandran, S.; Chugh, A.; Tiwari, A.; Narayan, J. Growth of highly conducting epitaxial ZnO-Pt-ZnO heterostructure on $\alpha-\mathrm{Al}_{2} \mathrm{O}_{3}\left(\begin{array}{l}0 \\ 0\end{array} 0\right.$ 1). J. Cryst. Growth 2006, 291, 212-217. [CrossRef]

20. Han, C.; Chen, D.; Zhang, Y.; Xu, D.; Liu, Y.; Kong, E.S.; Zhang, Y. High potential columnar nanocrystalline AlN films deposited by RF reactive magnetron sputtering. Nano Micro Lett. 2012, 4, 40-44. [CrossRef]

21. Thapa, R.; Saha, B.; Chattopadhyay, K.K. Enhanced field emission from Si doped nanocrystalline AlN thin films. Appl. Surf. Sci. 2009, 255, 4536-4541. [CrossRef]

22. Mirpuri, C.; Xu, S.; Long, J.D.; Ostrikov, K. Low-temperature plasma-assisted growth of optically transparent, highly oriented nanocrystalline AlN. J. Appl. Phys. 2007, 101, 024312. [CrossRef]

(C) 2017 by the authors; licensee MDPI, Basel, Switzerland. This article is an open access article distributed under the terms and conditions of the Creative Commons Attribution (CC-BY) license (http:/ / creativecommons.org/licenses/by/4.0/). 